Annual Review of Microbiology

Charles E. Clifton, Editor ; Sidney Raffel, Associate Editor; H. Albert Barker, Assogiete Editor. Vol. 2. Pp. viii+532. (Stanford, dur.: Annual Reviews, Inc. ; London : H. K. Intwis and Co., Ltd., 1948.) 6 dollars.

TN this, the second Volume of a new series of annual 1 reviews, appattempt is made to survey major aspects of the vigorous and ever-widening field of microbioldgy: Broadly speaking, the matter presenfeg ranges over the physiology, pathogenicity and gen ftic of fungi, bacteria, protozoa and viruses; but particular themes such as antibiotics, the nature of antibodies, the inheritance of immunity, the mode of action of therapeutic agents, nitrogen fixation, chemical disinfectants and the microbiology of soils, drinking water and sewage, have also received attention. In a work which is intended to provide up-todate information over a wide field, it would be invidious to pick out particular essays for special mention; indeed, as some of them run to forty or fifty odd pages, it would be difficult to do justice to any one of them in a short review. The reader is, however, assured of a wealth and diversity of information both in the text and in the comprehensive bibliographies.

Difierences of opinion doubtless exist as to the content and function of annual reviews. Those of the kind under consideration tend to be of the nature of compilations-in the preface the editors refer to "the task of compiling critical and, at the same time, comprehensive reviews". While the several papers included in the annual volume afford an adequate account of what is going on in particular fields, there can be little doubt that they will gain in value in so far as the attempt is made not only to carry out a paper-to-paper survey, but also to pick out and emphasize the major contemporary lines of advance and to summarize briefly the main conclusions which have been reached or to which the newpliscoveries point.

newplo

The kailure of Metals by Fatigue

Proceedings of a Symposium held in the University of Nielbourne, December 2nd-6th, 1946, under the ægis of the Faculty of Engineering. Pp. xvi +505 . (Melbourne: Malbofece University Press, 1947.) 42s. net.

$7 \mathrm{HE}$ holdinzof symposia to discuss present views on a partivular subject is becoming increasingly popular. Ekech provides the occasion for pooling availgble, scientific knowledge in a particular field, to the grept convenience of individual workers on the subject? The main benefit, however, as Dr. H. J. Gough says in his foreword to this volume, is in the provision "of a spring-board from which valuable researches will be launched".

Thirty papers read at a symposium in Melbourne in December 1946 are here collected. Two-thirds of the papers are by Australians, but the names of A. G. Pugsley, U. R. Evans and H. O'Neil are among those from Great Britain, with H. F. Moore and G. Sachs among the contributors from the United States. While the papers are generally of high quality, there is no important new contribution to our basic understanding of the phenomenon of fatigue. The papers give practical examples of the occurrence of fatigue failure in specific service conditions, analyse the conditions promoting reversed stresses of sufficient intensity and suggest methods by which failures could be avoided. Important summaries of our knowledge of the mechanism of fatigue failure are included, and there are papers on testing techniques which, although in some cases on the fringe of the field of fatigue failure, are nevertheless of considerable importance in its understanding or its investigation.

All papers are not of the same high level (for example, the writers on fatigue failures of lead cable sheathing seem inadequately informed on previous British work in this field), but the book is one which justifies the considerable trouble that the promoters of such a symposium must have taken. The absence of an index is deplored.

\section{Inorganic Process Industries}

G. L. BAILEY

By Prof. Kenneth A. Kobe.

Pp. vii +371 . (New York : The Macmillan Comnany ; London: Macmillan and Co., Ltd., 1948 1908 . net.

THIS book is intelded to impress on students the importance of following the evolution of an industry pof of keeping abreast with modern developments by tudying the literature. The first chapter gifosm. very comprehensive method of studying the lite ature. The remaining nine might better be entitled "Some Inorganic Industries in the United States", and consist of a series of descriptive articles, each of about 40 pages, on the main heavy-chemical industries. These are presented in a historical manner, contain no references, and do not emphasize new developments. At the end of each chapter a number of articles is listed as a recommendation for students to read. These are almost exclusively of American origin. Except for a few historical references, the subject-matter is confined to the manufacture of sodium and potassium salts, chlorine, sulphuric acid, and nitrogen and phosphorus compounds in the United States; and the book can scarcely be expected to appeal to British readers, in spite of an admirable set-up, clear diagrams and good printing.

The Works of George Berkeley, Bishop of Cloyne Edited by Prof. A. A. Luce and Prof. T. E. Jessop. (Bibliotheca Britannica Philosophica.) Vol. 1: Philosophical Commentfries, Essay towards a New Theory of Vision. Th ory of Vision Vindicated. Edited by Prof. A, AiLuce. Pp. viii +280 . (London and Edinburgh: Thomas Nelson and Sons, Ltd., 1948.) 30s. B.t.

7 HIS hist volume of the new complete edition of the works of Berkeley is most welcome and is a hanjisdme well-produced book worthy of its subject. Fraser's editions of 1871 and 1901 have been useful, but have some serious defects. Fraser discovered the notebooks containing Berkeley's "Philosophical Commentaries", but failed to see that they had been bound together in the wrong order. His transcription was not always accurate. Prof. Luce's magnificent edition of 1944 put right these defects and provided invaluable notes. He here reprints the "Commen. taries" in handier form with shorter notes, sufficient for explanatory purposes. The "New Theory of Vision" never presented serious textual difficulties; but Fraser did not distinguish properly the alterations made by Berkeley in his life-time and does not appear to have used the last version. Prof. Luce reprints this fourth and last edition, indicating all alterations. In his introduction, while stressing the permanent value of this work of Berkeley, he mentions a point often forgotten, namely, how much it owed to the influence of Molyneux. 